家蚕絹フィブロインの光脆化の進行度と

特異陷没現象との関連 ${ }^{*}$

$$
\text { ク゚ンビ株式会社研究所桑原昂** }
$$

\title{
RELATION BETWEEN THE DEGREE OF ADVANCING OF OPTICAL DESTRUCTION AND THE PECULIAR DEPRESSION PHENOMENA OF SILK FIBROIN OF BOMBYX MORI
}

\author{
By Akira Kuwahara \\ (Gunze Co., Ltd., Ayabe City, Kyoto, Japan)
}

In this paper, the observation of silk fibroin was performed in order to obtain the changes of their peculiar depression phenomena during the exposure to ultra-violet ray.

Silk fibroin of Bombyx mori wax exposed in textural form to ultra-violet ray for the different length of time in dry and wet states, and then the observation was made mainly about transition of the peculiar depression phenomena with the electron microscope and about variation of its physical properties.

Due to optically destructing action with ultra-violet ray, shallow linear or circular pepressions with partial cracks or partial strips were seen at the early stage of exposure, and with the increase of exposing time, depressed areas were seen expanded in both horizontal and vertical directions showing the destruction in the way of chain reacting and moreover showing the tendency of depressing and cutting the principal axis.

The phase of wet exposure was revealed more significantly and more severe than that of dry exposure.

Judging from the above result and variation of its physical properties, it can be conceived that those preculiar depression phenomena grow significant in proportion of the advance of the exposure and that those phenomena are due to weak-point of tyrosine area in silk fibroin.

(Received June 30, 1966)

\section{1. 腥言}

第 6 報1)に和いて，家量絹フィブロインは過酸化水素 酸化によって，その表面に陮没現象を生じ，また酸化の

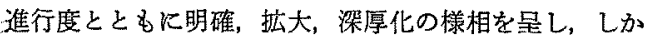
る他の脆化方法に和いては全く見られない特貲な現象で あることを報告した。

家查綟フィブロインに対する他の酸化作用と若えられ る紫外線に上る光脆化について，西2 ${ }^{2}$ は，湿㵎時の紫外 楾照射の場合は，通常の空気条件の場合に比乙脆化度が

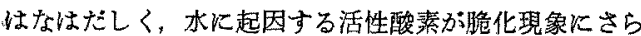

*この報文を「䋧系の脆化に関する電子䪶微鏡的研究 第 7 報 Electron Micrographic Investigation on the Destruction of Silk Fibers Part 7」とする。

** 現在の所属：厸島大学教育学部東雲分校
に拍車をかけると述へ，また中西》゙（日光懪簬による フィブロインの崩壤を, 強伸度, 微細搆造変化, 染着量 などの面から，水素結合の切断，チロシンの酸仁に続い て韭結晶領域の崩壊、さらに結晶格子の崩壊が特こると 推定している。

奥4)は，紫外線照射とチロシンの分解之の開俰をしら ベ，チロシンの酸化を指摘し，さらに前田5)，岡本(8)， 坂口 ${ }^{7)}$, 鈴木 ${ }^{8)}$, 山崎9), Leopold well10), 小幡 ${ }^{11)}$, 原 ${ }^{12)}$ により，紫外線照射にとるな5チロシン,トリプトファ ン，ヒリン，スレオニンなどの含量変化をしらへ，主と してチロシンに起因することを結諭つけている。

著者は，乾燥状態和よび湿潤状態において，紫外線に よる光脆化の進行度とともに，特與陷没現象がどよう に推移するか電子影徽鏡観祭を主体に，性状変化をるむ わせて究明したので，その結果について報告する。 


\section{2. 実験 方 法}

\section{$2 \cdot 1$ 供試誁料}

第 1 報 ${ }^{18)}$ 亿記载したと同様の 15 多付精練網羽二重を 供試試料とした。

\section{$2 \cdot 2$ 紫外楾照射方法}

15 多付精練絹羽二重をフィブロイン供試融料として, $50 \mathrm{~mm}$ (たて糸方向) $\times 150 \mathrm{~mm}$ (よこ糸方向) の大きさ に溒製し、アクメ水銀澄(島津製作所製)，100V，700VA 試料との距離 $250 \mathrm{~mm}$ で次のよ 5 に紫外線照射を行なっ to

（1）乾燥照射の場合は， $22^{\circ} \mathrm{C} ， 65 \% \mathrm{RH}$ の室内で， 本銀燈に上る試料近辺の温度上昇を防ぐため，常時つっ ンで邻却しなか゚ら，表裹それぞれ $2 ， 4 ， 8 ， 16 ， 32 ， 64$ 100，150，200 時間紫外線を照射した。

（2）湿潤照射の場合は，ビニールスポンシの上にガ 一ゼを招き，ビニールスポンジは常時吸湿状態とし，乙 かる一定水温にするため吸排水させ，その上に $50 \mathrm{mmx}$ $150 \mathrm{~mm}$ の試料をのせて，表敦えれでれ 1，2，4，8， $16 ， 32 ， 64 ， 80 ， 100 ， 150 ， 200$ 時間紫外線を照射乙 た。

\section{$2 \cdot 3$ 実験方法}

2·2，（1），(2）に記したよ5に，各時間，乾燥また 汢湿潤状態で紫外線照射した試料について, 動摩摖係 数, 強度，伸度吅上びその脆化率，徽細構造各領域量，
染料吸着能，着色度，䉓子顕徽鏡観察を第 1 報 ${ }^{13}$ に記载 したと同様の方法で実䮦した。

\section{3. 实験結果および考察}

\section{1 紫外線による光脆化作用}

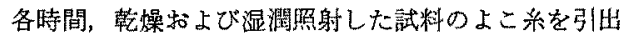
し，動摩嚓係数，強度，伸度および脆化率を测定した結 果の内，乾燥照射 Table 1, 湿润照射 Table $2 \mathrm{~K}$ 示した。何れる照射時間とともに強伸度は低下し，乾燥 照射に比し，湿润照射は一殷に脆化深が大きく，存在す る水分からの活性酸素儿起因するものと思方れる。

また湿潤照射の場合，照射の初期江強度に比し伸度 の低下が大きいが，照射が長くなると強度の低下が大と なり，乾燥照射の場合恃全般に伸度に比し强度の低下が

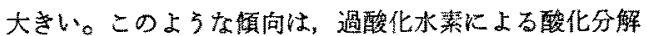
飞近似して抢り，光脆化か酸化現象である一つの示唆と 考光らるる。

したがって，柴外線によるこれらの強伸度挙動は，遇 酸化水䒱による酸化と同しく、ベプタイド鎖間の水菜結 合拉よびチロシン残基のフェノール性 $\mathrm{OH}$ 基とアスパラ ギン酸、グルタミン酸などの遊離の $\mathrm{COOH}$ 基間の水素 結合方切断され，さらにチロシンの酸化に基づく OH 基 の沿失や核の開裂などが起こることによるるのと推測さ れる。

動摩摖俰数は，照射時間に比例して減少し，乾燥照射

Table 1. Coefficient of friction, strength, elongation and degree of weakening of weft yarn of silk exposed to ultra-violet ray with the different length of time in the dry state.

\begin{tabular}{|c|c|c|c|c|c|c|c|c|c|c|c|}
\hline \multicolumn{2}{|c|}{ Time for exposure (hr) } & 0 & 2 & 4 & 8 & 16 & 32 & 64 & 100 & 150 & 200 \\
\hline \multicolumn{2}{|c|}{ Coefficient of friction } & 0.3710 & 0.3069 & 0.3172 & 0.2944 & 0.2543 & 0.2520 & 0.2473 & 0.2144 & 0.2033 & * \\
\hline \multicolumn{2}{|c|}{ Strength (g) } & 145.12 & 77.48 & 68.40 & 53.74 & 39.52 & 11.00 & 10.56 & * & * & * \\
\hline \multicolumn{2}{|c|}{ Elongation $(\%)$} & 18.74 & 11.24 & 12.04 & 11.04 & 8.08 & 6.06 & 4.86 & * & $*$ & * \\
\hline \multirow{2}{*}{$\begin{array}{l}\text { Degree of } \\
\text { weakening } \\
(\%)\end{array}$} & Strength & - & 46.61 & 52.87 & 62.97 & 72.77 & 92.42 & 92.72 & - & - & - \\
\hline & Elongation & - & 40.55 & 35.73 & 41.09 & 56.88 & 67.66 & 74.07 & - & - & - \\
\hline
\end{tabular}

* can't measured

Table 2. Coefficient of friction, strength, elongation and degree of weakening of weft yarn of silk exposed to ultra-violet ray with the different length of time in the wet state.

\begin{tabular}{|c|c|c|c|c|c|c|c|c|c|c|c|c|c|}
\hline \multicolumn{2}{|c|}{ Time for exposure(hr) } & 0 & 1 & 2 & 4 & 8 & 16 & 32 & 64 & 80 & 100 & 150 & 200 \\
\hline \multicolumn{2}{|c|}{ Coefficient of friction } & 0.3710 & 0.2638 & 0.2520 & 0.2496 & 0.2207 & 0.2207 & 0.2123 & $*$ & * & $*$ & * & $*$ \\
\hline \multicolumn{2}{|c|}{ Strength $(g)$} & 145.12 & 142.04 & 95.72 & 75.92 & 50.12 & 23.28 & 10.66 & * & * & * & $*$ & * \\
\hline \multicolumn{2}{|c|}{ Elongation $(\%)$} & 18.74 & 14.51 & 12.16 & 9.11 & 7.16 & 5.03 & 4.14 & $*$ & $*$ & $*$ & * & $*$ \\
\hline \multirow{2}{*}{$\begin{array}{c}\text { Degree of } \\
\text { weakening } \\
(\%)\end{array}$} & Strength & - & 2,12 & 34.04 & 47.68 & 65.46 & 84.65 & 92.65 & - & - & - & - & - \\
\hline & Elongation & - & 22.63 & 35.11 & 51.39 & 61.79 & 73.16 & 77.90 & 一 & - & - & - & - \\
\hline
\end{tabular}

* can't measured 
に比し湿潤照射の場合は総じて小さい数値を示してい る。

各試料の希酸加水分解法による微細構造の各領域量を 求めた結果は，赖噪照射の場合 Table 3 の溶出量変化

Table 3. Soluble amount (\%) of silk exposed to ultra-violet ray in the dry state with $2 \% \mathrm{H}_{2} \mathrm{SO}_{4}$ solution at $95^{\circ} \mathrm{C}$. (volume ratio. $1: 100$ )

\begin{tabular}{|c|c|c|c|c|c|c|c|c|}
\hline \multirow{2}{*}{\multicolumn{2}{|c|}{ Sample silk }} & \multicolumn{7}{|c|}{ Treated time $(\mathrm{hr}): 2 \% \mathrm{H}_{2} \mathrm{SO}_{4}$ at $95^{\circ} \mathrm{C}$} \\
\hline & & 2 & 4 & 6 & 8 & 10 & 12 & 14 \\
\hline Untreated & & 9.97 & 17.50 & 25.63 & 32.64 & 37.00 & 39.96 & 45.36 \\
\hline Time for & xp. $2 \mathrm{hrs}$ & 10.57 & 20.11 & 27.98 & 33.86 & 38.70 & 41.05 & 42.13 \\
\hline "I & $4 / /$ & 10.78 & 20.66 & 29.29 & 35.37 & 39.68 & 42.39 & 45.11 \\
\hline /I & $8 / \prime$ & 11.39 & 22.11 & 30.74 & 35.95 & 41.68 & 43.32 & 45. 12 \\
\hline$\prime \prime$ & $16 / /$ & 11.80 & 22.29 & 31.06 & 36.55 & 42.39 & 43.72 & 44.99 \\
\hline$\prime \prime$ & $32 \prime \prime$ & 12.61 & 23.53 & 32.31 & 37.49 & 43.72 & 44.92 & 46.73 \\
\hline$\|$ & $64 / /$ & 13.21 & 24.41 & 35.27 & 41.19 & 46.36 & 47.58 & 48.90 \\
\hline$\prime \prime$ & $100 \prime \prime$ & 17.88 & 32.63 & 40.51 & 47.46 & 48.66 & 49.83 & 51.08 \\
\hline$" \prime$ & $150 / /$ & 19.00 & 33.09 & 42.13 & 49.66 & 49.83 & 50.97 & 52.42 \\
\hline$\prime \prime$ & $200 \prime \prime$ & 26.81 & 40.64 & 50.17 & 51.64 & 53.29 & 54.23 & 55.39 \\
\hline
\end{tabular}

から Table $4 K$ ，史た湿潤照射の場合 Table 5 の溶出 量変化加ら Table 6 に示した。

何れも照射時間とともに非結晶領域，準結晶領域は增 大し，結晶領域は減少の傾向を示し，脆化にとるなって

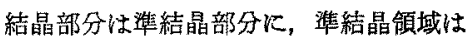
非結晶部分へと転移してゆく。

乾燥照射に比し湿潤照射の脆化度はは なはだしく，たとえば Table 4，6の結 果にみられるように1時間の湿潤照射は

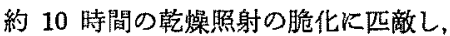
前述のように綟フィブロインは，紫外線 照射によって水素結合の切断とともにチ ロシンの酸化にとあならフィブロインの 開裂，崩㙏が起こるるのと考えられ，乙 加当紫外線照射の際の水分存在か;，湿潤 光脆化作用を一層過酷なるのとしている ことがわかる。

第 6 報1)に記した過酸化水素に上る酸 化の場合之同様，紫外線照射の際も，絹 フィブロインの脆化にともなって, 酸性

Table 4. The fine structure of silk exposed to ultra-violet ray in the dry state.

\begin{tabular}{|c|c|c|c|c|c|c|c|c|c|c|}
\hline Time for exp. (hr) & 0 & 2 & 4 & 8 & 16 & 32 & 64 & 100 & 150 & 200 \\
\hline Amophous $\mathrm{R}(\%)$ & 9.51 & 9.75 & 10.00 & 10.86 & 11.22 & 12.66 & 13.79 & 15. 12 & 15.81 & 16.78 \\
\hline Semicrystal $R$ & 21.89 & 20.81 & 21.55 & 23.04 & 23.89 & 24.04 & 26.34 & 27.36 & 28.06 & 30.54 \\
\hline Crystal & 68.60 & 69.44 & 68.45 & 66.10 & 64.89 & 63.32 & 59.87 & 57.62 & 56.13 & 52.68 \\
\hline
\end{tabular}

Table 5. Soluble amount (\%) of silk exposed to ultra-violet ray in the wet state with $2 \% \mathrm{H}_{2} \mathrm{SO}_{4}$ solution at $95^{\circ} \mathrm{C}$.

\begin{tabular}{cr|r|r|c|c|c|c|c}
\hline \multirow{2}{*}{ Sample silk } & \multicolumn{6}{|c|}{ Treated time (hr) $: 2 \%$} & $\mathrm{H}_{2} \mathrm{SO}_{4}$ solution at $95^{\circ} \mathrm{C}$ \\
\cline { 2 - 9 } & \multicolumn{1}{c|}{2} & 4 & 6 & 8 & 10 & 12 & 14 \\
\hline Unexpoped & 9.97 & 17.50 & 25.63 & 32.64 & 37.00 & 39.96 & 45.36 \\
Exposure for hr $1 \mathrm{hrs}$ & 11.18 & 20.85 & 29.45 & 35.51 & 41.19 & 42.53 & 44.22 \\
$\prime \prime$ & $2 \prime \prime$ & 12.20 & 22.47 & 31.38 & 37.13 & 42.29 & 43.70 & 44.99 \\
$\prime \prime$ & $4 \prime \prime$ & 13.21 & 24.06 & 33.25 & 39.40 & 44.61 & 45.74 & 46.98 \\
$\prime \prime$ & $8 \prime \prime$ & 19.00 & 32.47 & 41.32 & 48.66 & 50.06 & 51.75 & 53.18 \\
$\prime \prime$ & $16 \prime \prime$ & 39.29 & 41.05 & 50.74 & 52.09 & 53.61 & 55.29 & 56.40 \\
$\prime \prime$ & $32 \prime \prime$ & 37.27 & 52.96 & 54.35 & 55.49 & 57.30 & 58.84 & 59.78 \\
$\prime \prime$ & $64 \prime \prime$ & 36.40 & 48.78 & 59.03 & 60.70 & 62.03 & 63.62 & 64.97 \\
\hline
\end{tabular}

染料の吸看量は濑減し，壏基侳染料の吸 着量は漸増の䝨向を示す。これらの関保 について，Fig. 1 (乾燥・湿潤照射にと 石な5酸性染料吸着量), Fig. 2(乾燥・ 湿潤照射にともな5塩基性染料吸着量) に矢の結果を示した。湿潤照射の濹合の 吸着の減少叔よび增加率は，何れる乾燥 照射に比し相些大である。

これらの傾问は，過酸化水素による酸 化の場合と同粎であるが，その程度は紫 外線照射に招いて顕著でるることから， 紫外線による光脆化は，照射時間ととも に起こる激しい酸化作用に起因し，千口

Table 6. The fine structure of silk exposed to ultra-violet ray in the wet state.

\begin{tabular}{|c|c|c|c|c|c|c|c|c|c|}
\hline Time for exp. (hr) & 0 & 1 & 2 & 4 & 8 & 16 & 32 & 64 & 80 \\
\hline Amorphous $\mathrm{R}(\%)$ & 9.51 & 10.64 & 11.31 & 12.39 & 14.65 & 16.07 & 18.44 & 20.37 & - \\
\hline Semicrystal & 21.89 & 20.81 & 23.05 & 26.24 & 27.67 & 30.24 & 31.32 & 34.57 & - \\
\hline Crystal & 68.60 & 68.55 & 65.64 & 61.27 & 57.48 & 53.69 & 50.24 & 45.06 & - \\
\hline
\end{tabular}




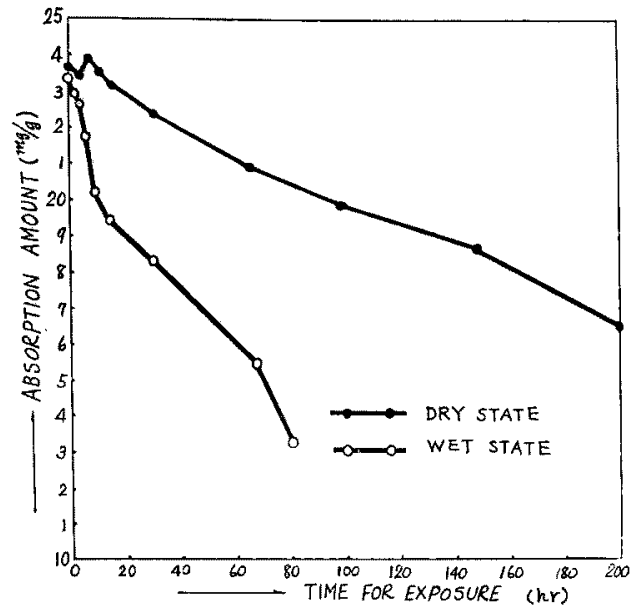

Fig. 1. Orange $\mathrm{G}$ absorption amount of silk expose to ultraviolet ray in the dry and wet states.

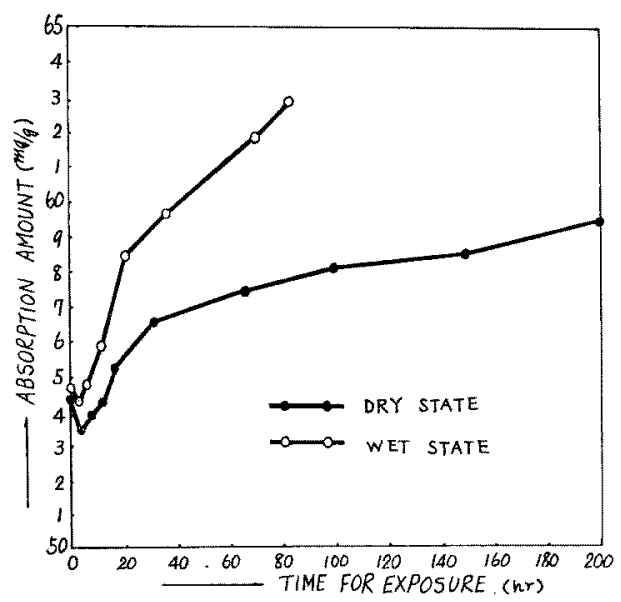

Fig. 2. Methyl orange absorption amount of silk exposed to ultraviolet ray in the dry and wet states.

シン量の減少にともならフェノール核の開裂捛よびペプ タイド鎖の一部切断から，相対的な $-\mathrm{COOH} の$ 堌加，酸 化脆アミノによる- $\mathrm{NH}_{2}$ の減少に起因するるのと思われ る。

紫外線照射とともに黄褐変着色現象を生じ，照射時間 と反射率の関伱について测定した結果を，Fig. 3(乾燥 照射)，Fig.4(湿潤照射) に示したが，時間とともに反 射率の低下率はなはだしく，特に湿潤照対の漊着色化が 明確である。

以上の結果から，乾燥照射に比し湿潤照射は，同一盼 間照射の場合数倍の光脆化をきたすこと（特に微細構造

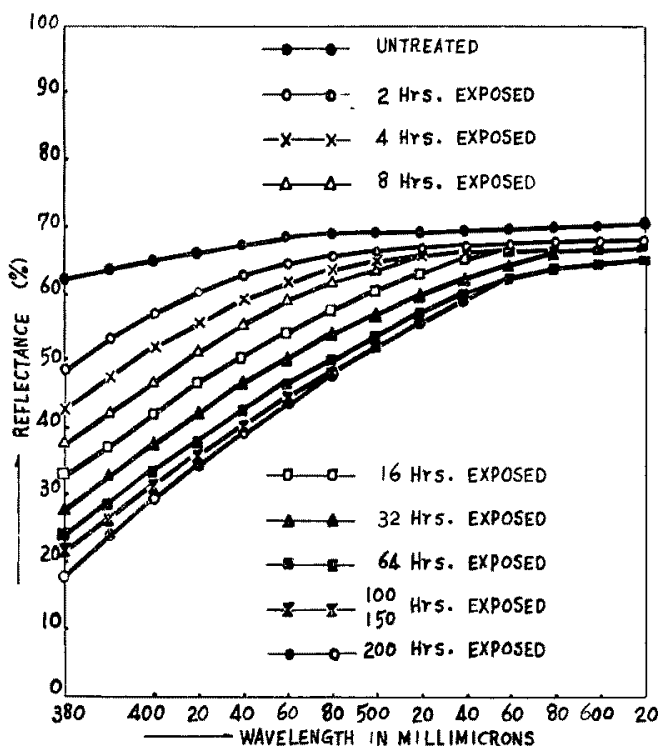

Fig. 3. Relation between reflectance (\%), wavelength $(\mathrm{m} \mu)$ and time of exposure (hr). Silk was exposed to ultraviolet ray in the dry state.

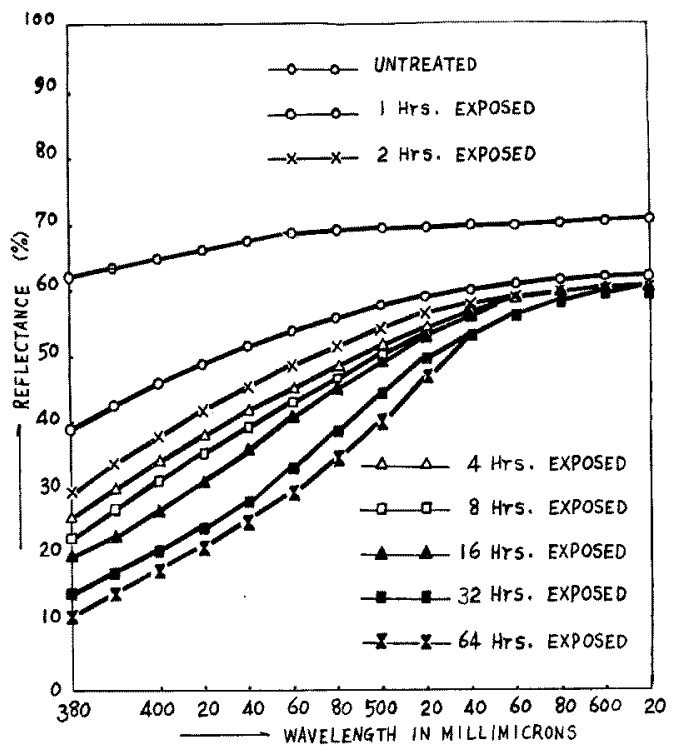

Fig. 4. Relation between reflectance $(\%)$, wavelengtn $(\mathrm{m} \mu)$ and time of exdosure.

Silk was exposed to ultraviolet ray in the wet state. 


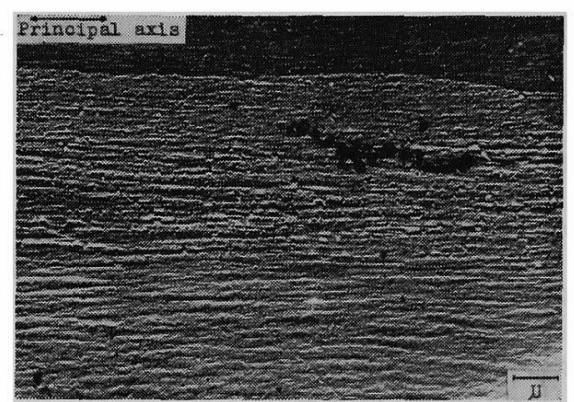

(Photo 0) Electron micrograph of untreated silk. (perfect degummed) $\mathrm{Cr}$ shadowed.

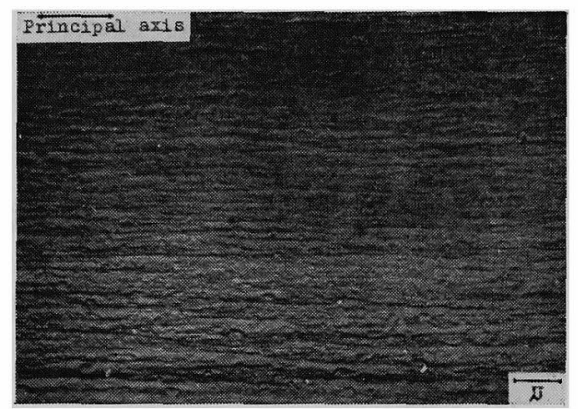

(Photo 1) Electron micrograph of silk exposed for 2 hours to ultra-violet ray in the dry state. Cr shadowed

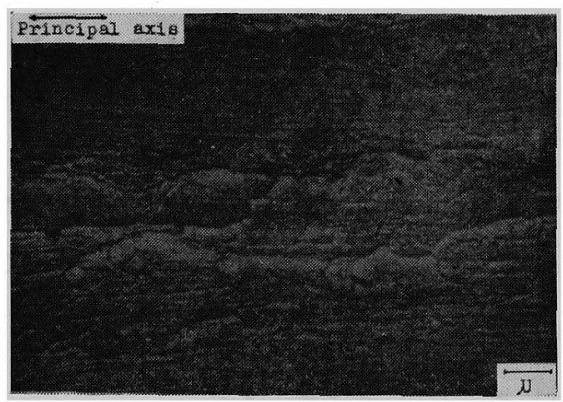

(Photo 2) Electron micrograph of silk exposed for 4 hours to ultra-violet ray in the dry state. Cr shadowed.

の各領域量変化の推移などから）が察知され，しかも第 6 報1) に述べた過酸化水素による酸化とほぼ同様の傾向 を示しているか，その脆化程度は過酸化水素よりも一層 過酷の酸化現象をうけるものと思われる。

\section{2 光脆化の進行度と特異宿没現象の推移(電子顕微} 鏡による表面構造の観察）

乾燥扣よび湿潤状態下で，各時間紫外線照射した試料 について, 特異陷没現象が照射時間とともにどのように 変化してゆくか, 電子顕微鏡観察により表面構造の推移

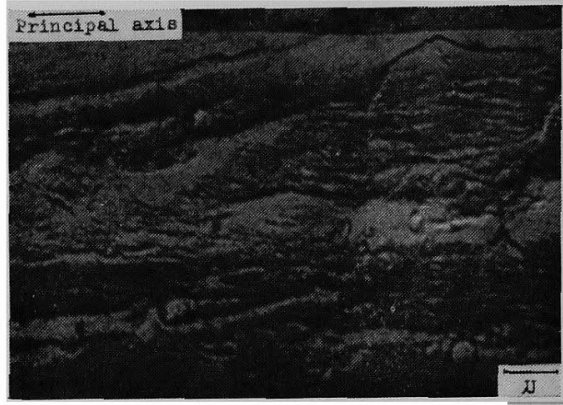

(Photo 3) Electron micrograph of silk exposed for 8 hours to ultra-uiolet ray in the dry state. Cr shadowed.

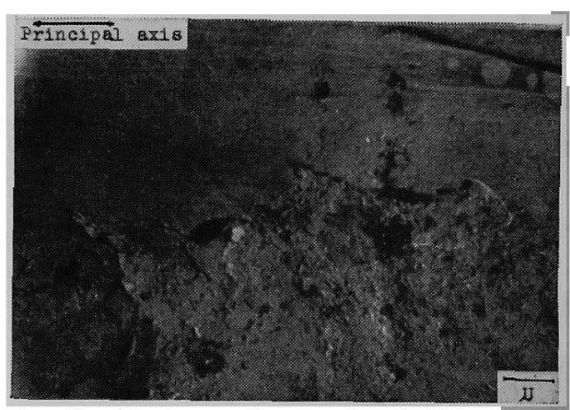

(Photo 4) Electron micrograph of silk exposed for 16 hours to ultra-violet ray in the dry state. $\mathrm{Cr}$ shadowed.

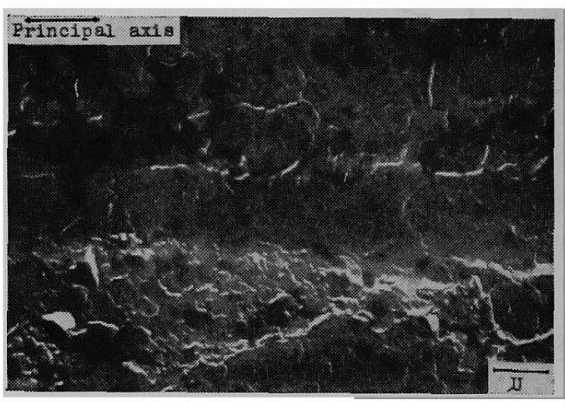

(Photo 5) Electron micrograph of silk exposed for 32 hours to ultra-violet ray in the dry state. Cr shadowed.

を究明した結果は下記のとおりである。

$3 \cdot 2 \cdot 1$ 乾燥状態に执子る紫外線照射時間と特異陥没 現象の推移

(Photo 0) 対照無処理区で, いわゆる通常のフィブ ロイン表面の構造を示し, 緎維軸方向に絨細な起伏状を 呈し, 一部精練時の作用のためかやや起伏の大きい部分 む見られる。

(Photo 1) 紫外線照射を 2 時間抢こなったもので, 非 結晶領域量 $9.75 \%$, 準結晶領域量 $20.81 \%$, 結晶領域 
量 $69.44 \%$ の領域比でほとんど対照無処理区と同一と考 えられる。表面の細かい起伏は，やや大きく粗となり， 無数の小孔が観察され，繊維表面の諸所の脆羽点が紫外 線により陥没したものと解される。

(Photo 2) 紫外線照射を 4 時間おこなったもので, 非結晶領域量 $10.00 \%$ ，準結晶領域量 $21.55 \%$, 結晶領 域量 68.45\%の領域比。(Photo 1) の小孔のうち，特に 弱いある脆弱点がさらに劣化され，この点を中心として 纎維軸方向に，かなり長い線状の陥没部分が数条見られ る。

(Photo 3) 紫外線照射を 8 時間おこなったもので, 非結晶領域量 $10.86 \%$, 準結晶領域量 $23.04 \%$, 結晶領 域量 66.10\% の領域比。やや劣化, 龟裂現象が進んで, 表面は不規則な凹凸状を呈し, 浅い面状陷没部分, 部分 的豩離が観察される。

(Photo 4) 紫外線照射を 16 時間おこなったもので, 非結晶領域量 $11.22 \%$ ，準結晶領域量 $23.89 \%$, 結晶領 域量 $64.89 \%$ の領域比。纎維表面に深度の浅い相当広面 積の陷没部分が見られ，その他の部分は扁平となり, 細 い起伏は消失している。これはある脆弱点一括そらくチ ロシンを起点とした部分と思われるーか゚，16 時間の紫

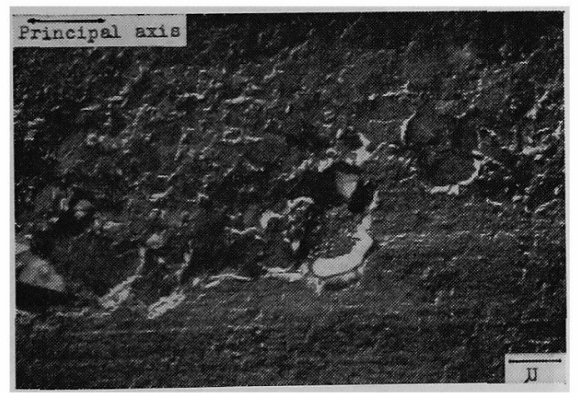

(Photo 6) Elecron micrograph of silk exposed for 64 hours to ultra-violet ray in the dry state. Cr shadowed.

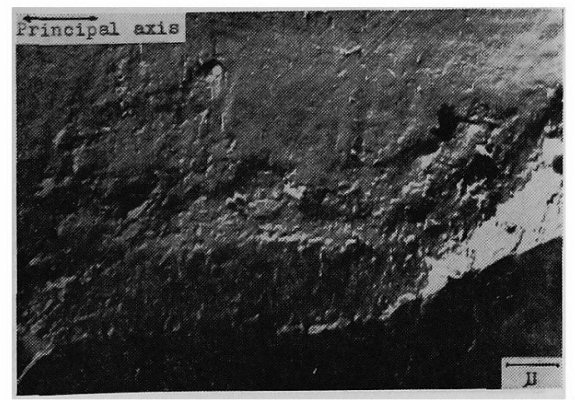

(Photo 7) Electron micrograph of silk exposed for 100 hours to ultra-violet ray in the dry state. $\mathrm{Cr}$ shadowed.
外線照射で劣化し，この部分を中心として周囲に抎大脆 化されたものと思われる。この陷没現象により，他の部 分は伸張され扁平化されたものであろう。

(Photo 5) 紫外線照射を 32 時間おこなったもので, 非結晶領域量 $12.66 \%$ ，準結晶領域量 $24.04 \%$ ，結晶領 域量 $63.32 \%$ の領域比。繊維軸方向にある幅をるった線 状の陥没部分がやや明確に見られ, そのため派生現象と して，他の部分は全般に扁平化された鱗片状を呈してい る。

(Photo 6) 紫外線照射を 64 時間おこなったもので, 非結晶領域量 $13.79 \%$, 準結晶領域量 $26.34 \%$, 結晶領 域量 59.87 の領域比。広い面積におよんで，大小様々の 集合性面状陥没部分が見られ, ある脆弱点の切断, 開裂 から連鎖反応的に拡大したものであろう。

観察の結果から, 深度は浅いように思われるが, 強伸 度の極端な低下からみれば，相当中心部まで波及してい るものと思われる。

(Photo 7) 紫外線照射を 100 時間おこなったもの で, 非結晶領域量 $15.12 \%$, 準結晶領域量 $27.36 \%$, 結 晶領域量 $57.62 \%$ の領域比。(Photo 5) の様相がさらに 劣化したものと思われるが，ある幅をもった線状陥没の

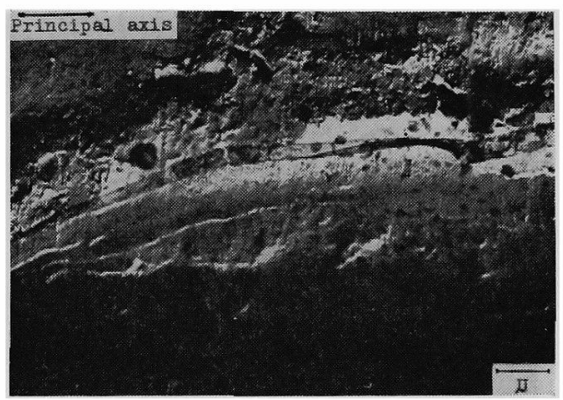

(Photo 8) Electron micrograph of silk exposed for 150 hours to ultra-violet ray in the dry state. Cr shadowed.

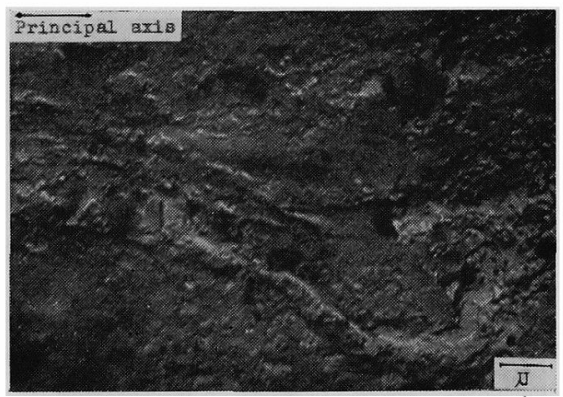

(Photo 9) Electron micrograph of silk exposed for 200 hours to ultra-violet ray in the dry state. $\mathrm{Cr}$ shadowed. 
主体をなすものは深度を增し,さらに面積を拡大して 様々な陥没現象を誘発している。

(Photo 8) 紫外線照射を 150 時間おこなったもの で, 非結晶領域量 $15.81 \%$, 準結晶領域量 $28.06 \%$, 結 晶領域量 $56.13 \%$ の領域比。強伸度の测定は不能で, 陥 没部分はその周壁の階段層状構造の形成に見られるよう に, さらに深度を增し, その底辺は粉砕様相を呈し, 紫 外線長時間照射による特異陥没現象が明確に判 別でき る。

(Photo 9) 紫外線照射を 200 時間扢こなったもの で, 非結晶領域量 $16.78 \%$, 準結晶領域量 $30.54 \%$, 結 晶領域量 $52.68 \%$ の領域比。強伸度の測定はできない。 極度の陥没現象のため，この部分を中心に旋回集合破断 し，全体に無定形を呈し繊維状を消失しているよ5に思 われる。

$3 \cdot 2 \cdot 2$ 湿潤状態における紫外線照射時間と特異陥伇 現象の推移

(Photo 10) 湿潤状態で紫外線照射を 1 時間おこなっ たもので, 非結晶領域量 $10.64 \%$, 準結晶領域量 20.81 $\%$, 結晶領域量 $68.55 \%$ の領域比。対照無処理区と大差 ないが，緎維軸方向に大小の深度の浅い線状陷没部分が

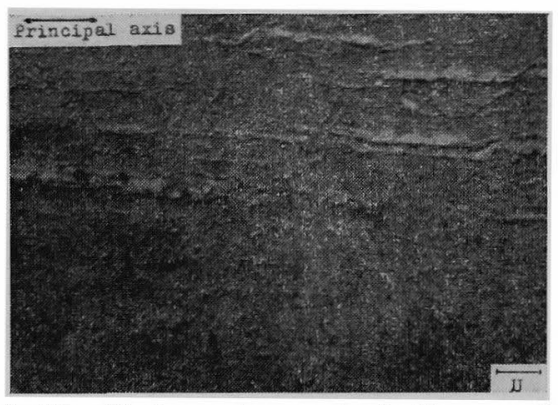

(Photo 10) Electron micrograph of silk exposed for 1 hours to ultra-violet ray in the wet state. Cr shadowed.

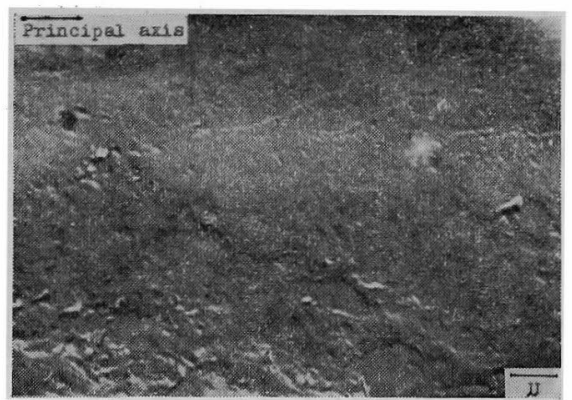

(Photo 11) Electron micrograph of silk exposed for 2 hours to ultra-violet ray in the wet state. Cr shadowed.
数条見られ，緎維束状および分岐緎維状部分もかなり明 瞭に観察される。

(Photo 11) 湿潤状態で紫外線照射を 2 時間おこなっ たもので, 非結晶領域量 $11.31 \%$, 準結晶領域量 23.05 $\%$, 結晶領域量 $65.64 \%$ の領域比。(Photo 10) の線状 陥没部分扰よびその周囲は，引続き紫外線作用により， 脆化のはなはたしい部分は同浴水中に流出し，新たに小 さい面状陷没が出現し表面は全般に扁平となっている。

(Photo 12) 湿潤状態で紫外線照射を 4 時間おこなっ たもので, 非結晶領域量 $12.49 \%$, 準結晶領域量 26.24 $\%$, 結晶領域量 $61.27 \%$ の領域比。かなり深い数条の線 状陥没部分が明確に観察され, 前記微細構造の变化, 強 度低下率からみて, 繊維の表面または表面に近い部分に とどまらずある程度中心部近辺にも波及しているよ5に 思われる。

(Photo 13) 湿潤状態で紫外線照射を 8 時間おこなっ たもので, 非結晶領域量 $14.85 \%$, 準結晶領域量 27.67 $\%$, 結晶領域量 57.48 の領域比。広い面積におよふ面状 陷没現象一これは脆弱点を中心に紫外線照射とともにそ の脆化域を㧪大し，同浴水との併作用により陥没したも の一，一部には線または点状の陥没も見られ，(Photo

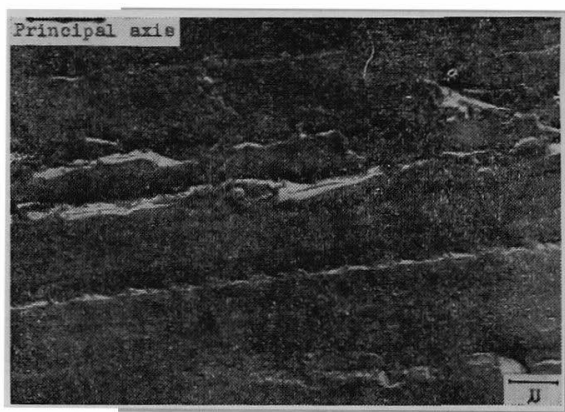

(Photo 12) Electron micrograph of silk exposed for 4 hours to ultra-violet ray in the wet state. Cr shadowed.

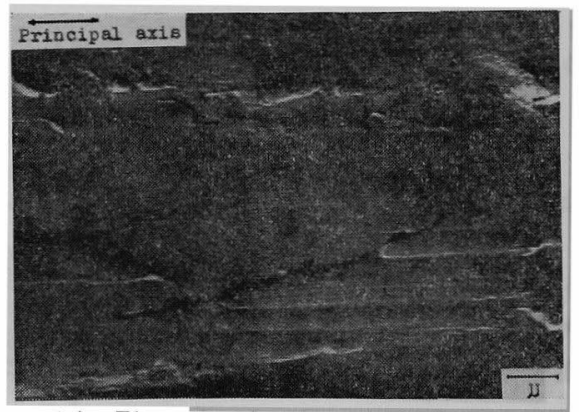

(Photo 13) Electron micrograph of silk exposed for 8 hours to ultra-violet ray in the wet state. $\mathrm{Cr}$ shadowed. 
12）よりさらに劣化された様相がうかがわれる。

(Photo 14) 湿潤状態で紫外線照射を 16 時間おこな ったもので，非結晶領域量 $16.07 \%$ ，準結晶領域量 $30.24 \%$, 結晶領域量 $53.69 \%$ の領域比。大小の棈円陥 没部分が㵶維軸方向に見られる。

(Photo 15) 湿潤状態で紫外線照射を 32 時間おこな ったもので, 非結晶領域量 $18.44 \%$ ，準結晶領域量 $31.32 \%$ ，結晶領域量 $50.24 \%$ の領域比。脆くて単に繊 維状を形成しているにすぎない思われる様相を呈し,

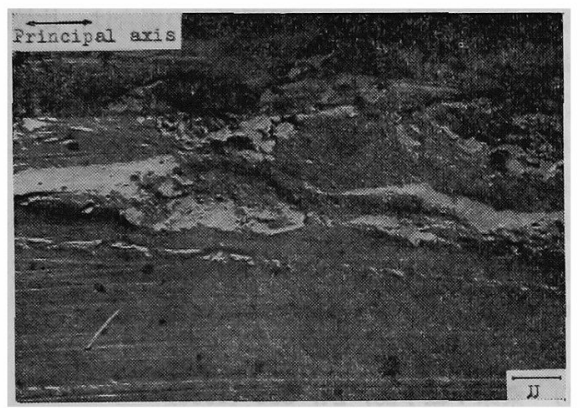

(Photo 14) Electron micropraph of silk expoed for 16 hours to ultra-violet ray in the wet state. Cr shadowed.

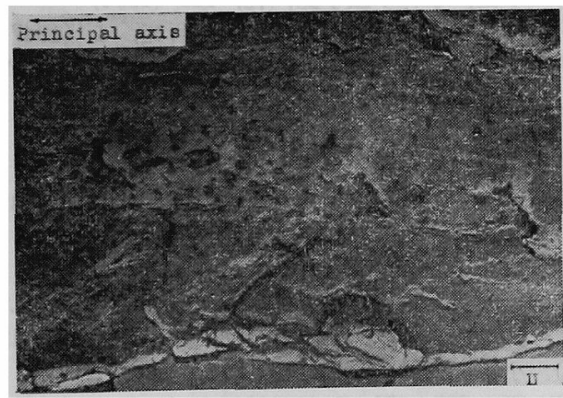

(Photo 15) Electron micrograph of silk exposed for 32 hours to ultra-violet ray in the wet state. Cr shadowed.

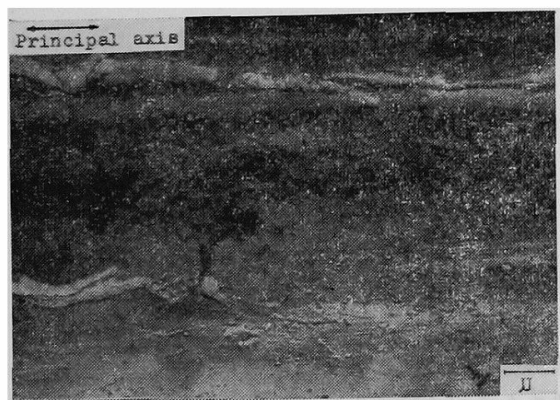

(Photo 16) Electron micrograph of silk exposed for 64 hours to ultra-violet ray in the wet state. Cr shadowed.
非常に広範囲に拉よぶ大きな陥没部分, そしてその部分 にも多少の凹凸が散見され, 明らかに劣化, 脆弱症状を 呈している。

(Photo 16) 湿潤状態で紫外線照射を 64 時間扣こな ったもので，非結晶領域量 $20.37 \%$ ，準結晶領域量 $34.57 \%$, 結晶領域量 45.06 の領域比。脆化はなはだし く強伸度の測定は不能。織維の表面は大部分陥没してい るが，ところどころにその未陥没部分が虫食状を呈して 残存している。(Photo 15) の様相がさらに劣化したも のと考学られる。

(Photo 17) 湿潤状態で紫外線照射を 80 時間おこな ったもので, 短時間で希酸溶解し, 微細構造各領域な らびに強伸度の测定不能。階段的な深度をもった大陥没 部分が明確に見られ，極度の脆化作用がうかがわれる。

(Photo 18) 湿潤状態で紫外線照射を 100 時間おこな ったもので, (Photo 17) 同様脆化はなはだしきため微 細構造各領域ならびに強伸度の測定は不能。(Photo 16) に見られた様相が，さらに劣化したものと思われ，繊維 軸方向の長いしかも幅をもった線状陌没, 全幅を綎断し た繊維軸切断が観察される。

以上の電子顕微鏡による観察結果から，紫外線照射時

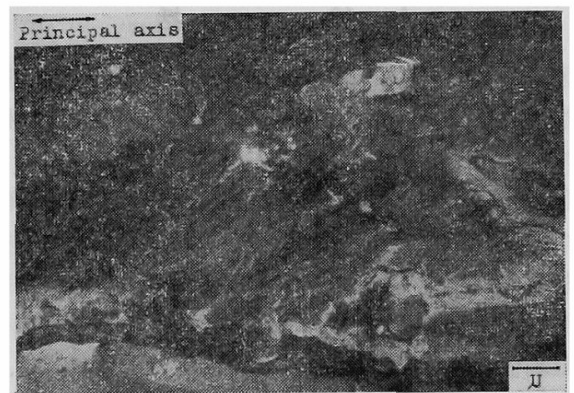

(Photo 17) Electron micrograph of silk exposed for 80 hours to ultra-violet ray in the wet stete. Cr shadowed.

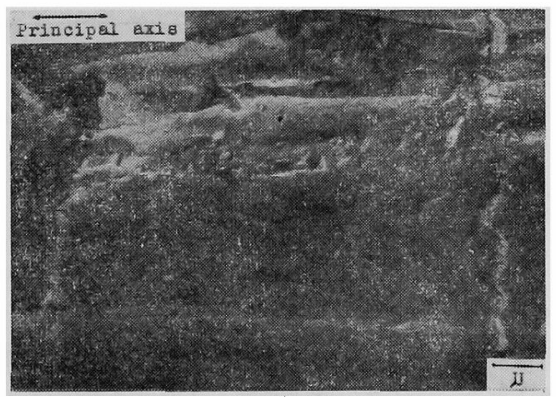

(Photo 18) Electron micrograph of silk exposed for 100 hours to ultra-violet ray in the wet state. Cr shadowed. 
間の初期に叔いては，瀻維表面の無数の小孔，濯度の浅 い線状なたは面状陷没および一部に軽度の龟裂，部分㔀 離などが見られるが，微細棈造の各領域量変化は僅少で あるにるかかわらず，強伸度の低下が蹎著であることか ら考えて，これらは織維の表面または表面上り比較的近 距離に存在するチロシンなどを主体とした脆弱点を中心 に，やや浅い深度で主として周囲の方向にその陷没領域 を広げてゆくものと思われる。

さらに柴外線照射時間の增加とともに，周围の方向， 深さの方向にその陷没領域を搪大し，非結晶領域から準 結晶領域，結晶領域へとチロシンなどを含さ数多くの脆 弱点を拠点として連鎖反応的に光脆化し，特に湿潤照射 の場合は，比較的短時間に，明確にこのよ 5 な傾向を示 し，最終的には緎維軸方向の随所に蛙いても陷没，切断 現象をうけることが察知される。

すなわち，照射時間とともにチロシンなどを主体とし た部分を中心に連鎖劣化し—したがって過酸化水第に 上る酸化の場合と同様，光脆化の場合る当然，チロシン 量は減少してゆくものと思われる一特異陷没現象は, 表面から中心部へと面積，深さを熄大しながら脆化して ゆく様相が観察できる。

\section{4. 総括}

家虫絹フィプロインの紫外線による光脆化の進行度と

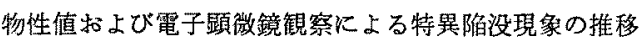
との間に，どのような関連性があるかを究明した。

（1）紫外線照射による光脆化は，照射時間量に併行 して強伸度の低下，徽細構造の各領域量変化，酸性染料 の吸着量の濑減，塩基性染料の吸着量の漸堌，黄褐変着 巴度の增加牧どの関係から，乾燥状態よりる水分存在下 の湿潤状態において，はるかに脆化がはなはたししく， し 加も両状熊の傾向は，何的も過酸化水素による酸化現象 に近似していること，紫外線による光脆化は酸化分解で
あること，過酸化水素酸化より一層過酷であることが判 明した。

（2）電子顕徽鏡峴察による特異陥没現象との関 係 は，紫外線照射の初期には比較的深度の浅い線状または 面状陌没，一部には派生的に生じた軽度の龟裂，部分䟝 離が見られ，照射時間の增加とともに，周囲深さの方向 にその陷没領域を㳎大し，非結晶領域から準結晶領域へ とチロシンなどを主体とした脆弱点を拠点として連鎖反 応的飞脆化し，最終的火は瀻維軸方向の随所火陥没切断 の様相がよく観察できる。湿潤熙射の場合は，比較的短 時間にしかし明確に，これらの傾向が判明した。

(付 記)

本研究について, ご指尊, ご援助をたまわった九州大 学阿久根了教授，渡辺忠雄助教授に謝意を表する。

原稿のご校閴をたまわった当社，村上頼之輔取締役， 太田良信氏に深謝するとともに，実験に協力いただいた 当社，高沢弘明，佐↔佳子兩氏に感謝する。

文献

1）桑原；織学誌，24、330（1968）

2）西；日亘雑， 25，357(1956)

日者雑，25，361 (1956)

日蛋雑，23，97(1957)

3）中西，小林；絾学誌，10，128 (1954)

4）奥住か；㞼釆品質向上理化学研究，I（1947）

5）前田，村瀬；蟫系品筫向上理化学研究，I（1947）

6)同本, 木村；緎学誌，10，12(1954)

岡本，菊池；日查稚，27，6(1958)

7）坂口，小笠原；信州大緎維報，9（1959）

8）鈴木，山崎; 日本雷系学全，講演要旨（第 31 回 大会）（1961）

9）山崎；查系研究，47，92（1963）

10) Leopold Well, William G. Gorden, A. R. Buchert; Arch. Biochim. Biophs., 33, 90 (1951)

11）小幡，坂村；日化，73，811（1952）

12) 原：農化，34，6(1960)

13）桑原；䄉学誌，23，477（1967） 